\title{
Targeting the gut microbiome in allogeneic hematopoietic stem cell transplantation
}

\author{
Marcel A. de Leeuw \& Manuel X. Duval, GeneCreek
}

\section{Contents}

Introduction

Materials \& Methods

Data analysis

\section{Results}

Overall GM composition evolution across allo-HSCT . . . . . . . . . .

Correlation between conditioning and the GM Baseline GM composition and survival . . . aGvHD cases, controls and GM composition Immuno-modulating metabolites . . . . . . 4 In silico screening of the allo-HSCT GM . . . 4

Discussion

Conclusions

Summary

Declarations

Bibliography

\section{List of Figures}

1 GM composition evolution across allo-HSCT . . . . 2

2 Baseline GM composition and conditioning level . . 3

3 Top 10 variable importances estimated by the random survival forest models . . . . . . . . . . . . 3

4 Biological safety level and aGvHD at onset . . . . 3

5 Relative importance of regressors explaining the aGvHD status . . . . . . . . . . . . . 3

6 Co-exclusion by and co-occurrence with QPS species 4

List of Tables

1 Prospective data sets used in the study . . . . . . 1 
medRxiv preprint doi: https://doi.org/10.1101/2020.04.08.20058198; this version posted June 9, 2020. The copyright holder for this preprint

(which was not certified by peer review) is the author/funder, who has granted medRxiv a license to display the preprint in perpetuity.

Revised manuscript

It is made available under a CC-BY-NC-ND 4.0 International license .

\title{
Targeting the gut microbiome in allogeneic hematopoietic stem cell transplantation
}

\author{
Marcel A. de Leeuw \& Manuel X. Duval, GeneCreek
}

Background. Gut microbiota (GM) composition has been associated with acute Graft-versus-Host Disease (aGvHD), however, current knowledge is insufficient to target the GM.

Methods. A relevant series of microbiome data sets were combined and reanalyzed, with resolution of species level changes in the GM.

Results. GM composition was found strongly correlated with aGvHD status after one month post stem cell infusion (R2=0.51). The predicted average biological safety level, indicative of antibiotic resistance, was found increased in aGvHD cases $(p=1.6 \mathrm{E}-4)$. Using in silico modelling, we formulated a probiotic composition putatively competing with mortality and aGvHD associated species.

Implications. Supplementation with Bifidobacterium longum and Bifidobacterium breve is proposed as a prophylactic treatment alongside with prebiotics and an adapted antibiotics course.

\section{Introduction}

Allogeneic Hematopoietic Stem Cell Transplantation (allo-HSCT) is a curative option for many patients with high-risk hematopoietic malignancies and hematological disorders. The success of allo-HSCT can be hampered by a process in which donor-derived T cells recognize host healthy tissue as non-self, causing an immunemediated complication known as acute Graft-versusHost Disease (aGvHD), predictive for morbidity and mortality of the patients. Even among transplants sourced from HLA-matched siblings, aGvHD occurs in $40 \%$ of recipients and reaches $50-70 \%$ with unrelated donor HSCT, yet less than half of the patients who develop aGVHD experience a response [6]. Bacterial LPS has been proposed as a triggering factor for aGvHD, based on murine models [7]

In patients undergoing allo-HSCT, antibiotics are routinely prescribed to reduce the risk of opportunistic infections. Antibiotics can profoundly impact gut microbiome (GM) composition and it has been shown broad spectrum antibiotics used after allo-HSCT increase the risk of aGvHD in mice and humans [8,9]. On the other hand, gut decontamination (GD), i.e. the complete suppression of the GM, has been shown to prevent aGvHD following allo-HSCT, but is difficult to achieve $[10,11]$. As a matter of fact, no standardized protocol for prophylactic and peri-transplant antibiotic treatment has been established as standard of care across transplantation centers.

It has been reported that autologous fecal microbiota transfer (auto-FMT) can in some instances restore the baseline GM after antibiotics courses applied during the allo-HSCT $[1,12]$. Of note, this baseline GM is potentially already disturbed, as a possible side effect of chemotherapy [13]. Hence some centers practice probiotics and $3^{\text {rd }}$ party FMT reconditioning of GM once the antibiotic treatment has been ended $[11,14]$. Third party FMT is also practiced with success for the treatment of steroid refractory aGvHD [15-18].

A lower GM diversity index at the time of engraftment (neutrophil recovery) has been associated in multiple studies with increased incidence of intestinal aGvHD disease and transplant related mortality (TRM) [19-24]. Enterococci have been proposed as a landmark for aGvHD whether induced by antibiotics or not $[25,26]$, whereas intestinal Blautia has been found associated with reduced death from aGvHD [27]. It has also been reported that at the time of engraftment, decreased Lachnospiraceae and Ruminococcaceae and increased Enterobacteriaceae correlate with aGvHD development and a lowered Treg/Th17 ratio [22].

We combined a series of relevant microbiome studies, available in the form of raw 165 data, in order to increase statistical power and investigate detailed baseline and aGvHD onset microbiome composition in relation to therapeutic outcome. At baseline we found that pre-conditioning regime is associated with the GM composition and that composition is correlated with survival. We found that from one month post stem cell infusion onward, aGvHD cases and non-aGvHD controls have distinguishable GM. We predicted relative gene abundance differences for several metabolites of interest. Finally, we predicted qualified presumption

Table 1: Prospective data sets used in the study. SRA: short read archive id, Qiita: Qiita index number, https://qiita.microbio.me, N: number of patients, n: number of samples, 16S: variable regions covered. *unpublished.

\begin{tabular}{|c|c|c|c|c|c|c|c|}
\hline BioProject & SRA & Qiita & $\mathrm{N}$ & $\mathrm{n}$ & $16 \mathrm{~S}$ & publ. & study details \\
\hline PRJNA491657 & SRP162022 & & 736 & 2,794 & V4-V5 & [1] & 735 HCT patients with auto-FMT, Iongitudinal \\
\hline PRJEB16057 & ERP017899 & 10,564 & 48 & 48 & V4 & [2] & 25 GvHD patients, 23 matched controls and 16 donors, baseline \\
\hline PRJNA602484 & SRP243841 & & 61 & 61 & V3-V4 & * & 31 GvHD patients and 30 matched controls, aGvHD onset \\
\hline PRJEB23820 & ERP105598 & & 26 & 84 & V3-V4 & [3] & 15 GvHD patients and 11 matched controls, longitudinal \\
\hline PRJNA592853 & SRP234378 & & 20 & 104 & V3-V4 & [4] & 10 GvHD patients and 10 matched controls, longitudinal \\
\hline PRJEB28845 & ERP111102 & & 19 & 246 & V4 & [5] & 4 GvHD patients and 15 matched controls, longitudinal \\
\hline
\end{tabular}


medRxiv preprint doi: https://doi.org/10.1101/2020.04.08.20058198; this version posted June 9, 2020. The copyright holder for this preprint

(which was not certified by peer review) is the author/funder, who has granted medRxiv a license to display the preprint in perpetuity.

Revised manuscript

It is made available under a CC-BY-NC-ND 4.0 International license .

of safety (QPS) species which could potentially be used as prophylaxis to control detrimental species, respect control-associated species and improve outcomes.

\section{Materials \& Methods}

The materials summarized in Table 1 have been made available in the form of raw $16 \mathrm{~S}$ data sets in the short read archive (SRA). Five of the six collected data sets have been made available as part of scientific publication. Four of the data sets are from longitudinal GM studies. Only one data set, ERP017899, was published with extensive per sample metadata, but for all but one data set, SRP162022, aGvHD status information was available.

\section{Data analysis}

Amplicon Sequence Variants (ASVs) were generated with the R Bioconductor package dada2, version 1.12.1 with recommended parameters [28], involving quality trimming, discarding of sequences with N's, assembly of forward and reverse sequences and chimera removal, as described previously [29]. Further analysis involved multiple alignment with mafft, version 6 [30] and approximately-maximum-likelihood phylogenetic tree generation with FastTreeMP, version 2 [31].

Taxonomic classification of ASVs was performed by an in-house Python and R program using random forest based supervised learning on the Ribosomal Database Project (RDP) release 11.5. Phenotypic content of microbiomes was inferred using species-level taxonomic assignments only and an in-house phenotypic database which has been initiated with information from BacDive [32] and the IJSEM journal [33] and has been hand-curated since. Resulting classifications and microbiome phenotypes are available from the Github repository https://github.com/GeneCreek/GvHD-manuscript in the form of Phyloseq $\mathrm{R}$ data objects.

Random forest survival analysis was carried out with the R package ranger, version 0.12.2.

aGvDH status regression analysis, with relative abundance of taxa resolved at the species level as independent variables, was performed using the $\mathrm{R}$ package relaimpo [Groemping, Ulrike [34].

Relative gene abundance prediction was performed using in-house R code, correcting for 165 copy numbers using the rrnDB version 5.4 [35] and using UniProt [36] provided per species non-redundant proteome counts and per species gene counts.

Co-exclusion and co-occurrence between species for probiotics composition were computed using $\chi^{2}$ testing on detectable presence of species in samples $(n=21,197)$ from a set of clinical- and crowd sourced 165 studies, all performed on the Illumina platform, Table 1 and supplemental Table S2.

Downstream analysis scripts covering the figures presented in the manuscript are available from https:
//github.com/GeneCreek/GvHD-manuscript.

\section{Results}

\section{Overall GM composition evolution across allo-HSCT}

Data set SRP162022 comprises patients undergoing allo-HSCT $(n=736)$ of which 14 received an auto-FMT 49 days after stem cell infusion, Fig. 1. GvHD status of patients was not available in the metadata for this data set. Recovery of Shannon species diversity seems to be boosted through auto-FMT, whereas strict anaerobes were not recovered. The antimicrobial resistance of the microbiome decreased, as reflected by the average biological safety level (BSL), which means that a less pathogenic GM was recovered through auto-FMT.
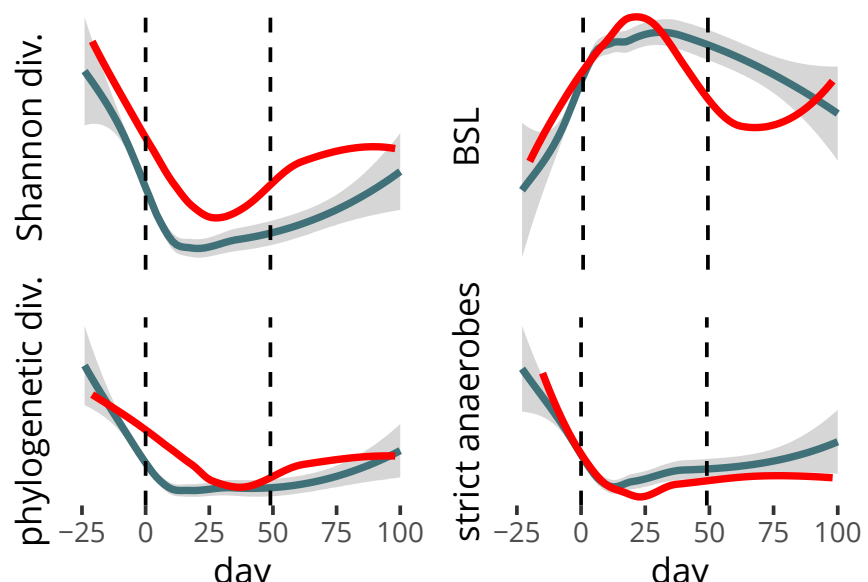

Figure 1: GM composition evolution across allo-HSCT. Data set SRP162022, 736 patients receiving stem cell infusion day 0. 14 patients (red) received an auto-FMT day 49. BSL: biological safety level.

\section{Correlation between conditioning and the GM}

Data set ERP017899 contains immunosuppressive conditioning intensity specification and baseline GM samples of 48 patients before stem cell infusion. The conditioning was qualified as low, intermediate or high with few cases of high conditioning. We regrouped the intermediate level with the high level and tested various GM composition covariates comparing the two regimes. The Shannon species richness and the strict anaerobe proportion - the proportion of anaerobes that are obligate anaerobes - reached significance, Fig. 2. Both criteria also reach significance when comparing the baseline patient GM with donor GM, supplemental Fig. S1. Furthermore, the use of the immunosuppressant cyclosporine, which in data set ERP017899 is mutually exclusive with the use of tacrolimus, is correlated with the over-representation of gram-positive bacteria, supplemental Fig. S2. 
medRxiv preprint doi: https://doi.org/10.1101/2020.04.08.20058198; this version posted June $9,2020$. The copyright holder for this preprint

(which was not certified by peer review) is the author/funder, who has granted medRxiv a license to display the preprint in perpetuity.

Revised manuscript

It is made available under a CC-BY-NC-ND 4.0 International license .

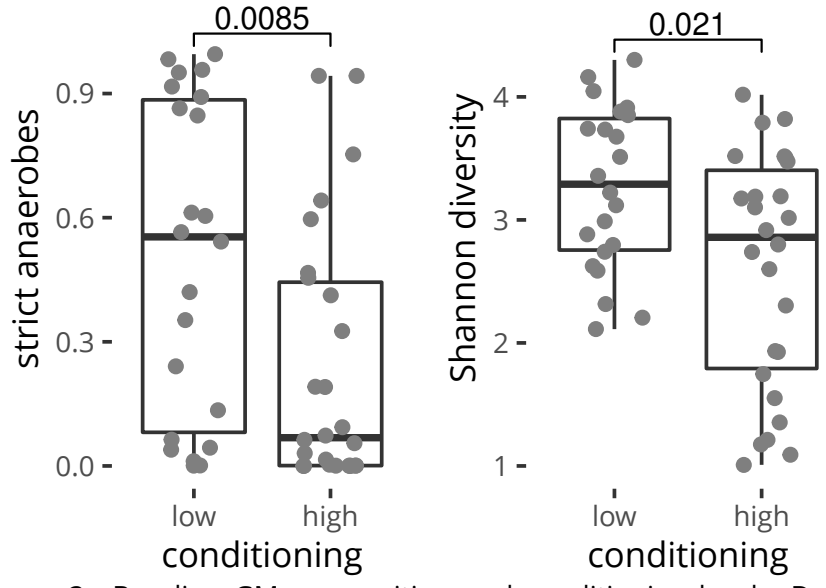

Figure 2: Baseline GM composition and conditioning level. Data set ERP017899, baseline samples of 41 patients who underwent alloHSCT. Numbers reflect Wilcoxon signed rank test p-values.

\section{Baseline GM composition and survival}

Data set ERP017899 contains baseline GMs and survival information for up to two years of 41 patients who underwent allo-HSCT. In brief, we fitted random survival forests (RSF) using log scaled relative abundances of taxa resolved at the species level as independent variables. Variable importance and associated $p$-values were estimated using permutations. We retained $p<0.05$ taxa as selected variables and the experience was repeated 50 times. Final models were built using 20 fold cross validation and a subset of taxa selected at least 10 times. Model performance was assessed using the integrated Brier score (IBS) and the best performing model was retained.

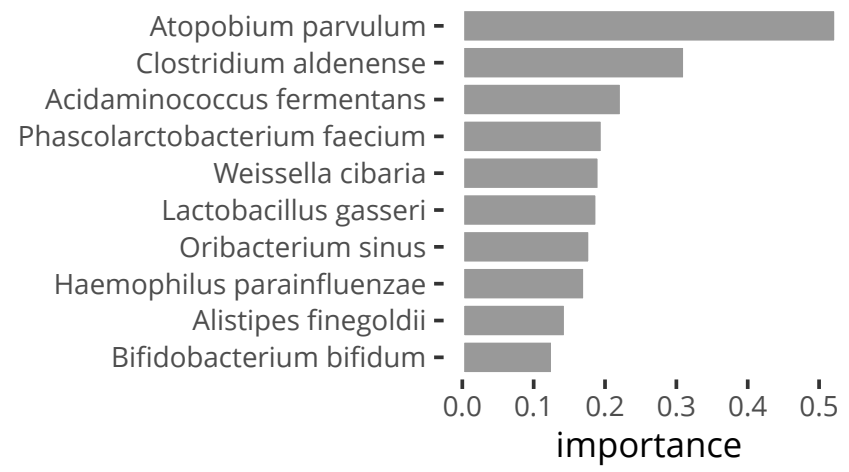

Figure 3: Top 10 variable importances estimated by the random survival forest models. Data set ERP017899, 41 patients who underwent allo-HSCT, with right-censoring of survival up to 2 years. All selected species are associated with mortality.

This model used 10 taxa, Fig. 3 and had an IBS of 0.153 . All selected taxa had higher average relative abundance at baseline in patients who subsequently deceased during the two year censoring time span.

\section{aGvHD cases, controls and GM composition}

We combined data sets SRP243841, ERP105598, SRP234378 and ERP111102 into a 84 patients and 178 samples data set comprising samples taken one month past stem cell infusion or beyond with matched controls. We defaulted to a case/control analysis not disposing of detailed aGvHD censoring information for these data sets. There is a significant difference in the inferred average biological safety level between the two patient groups, Fig. 4.

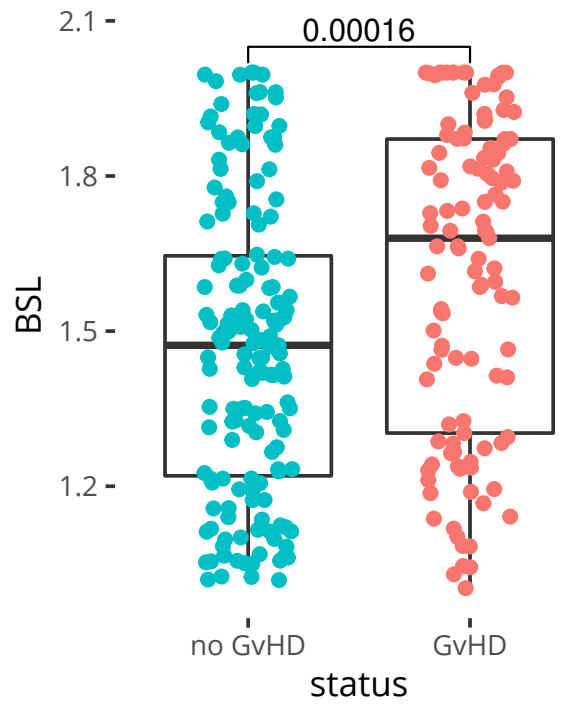

Figure 4: Biological safety level and aGvHD at onset. Combined data sets SRP243841, ERP105598, SRP234378 and ERP111102 - 84 patients and 178 samples. BSL: inferred average biological safety level of the microbiome. Numbers reflect Wilcoxon signed rank test p-values.

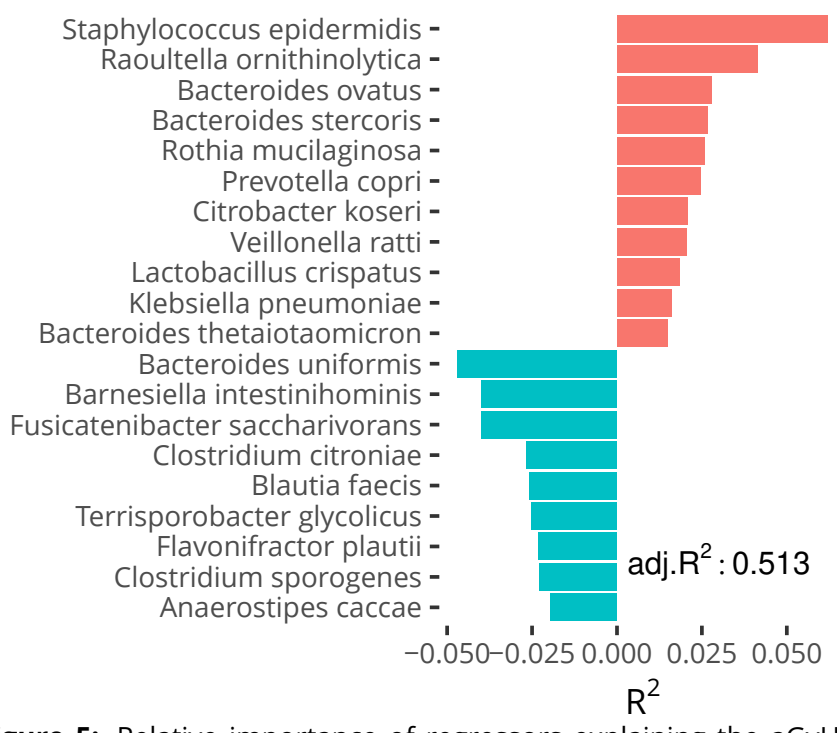

Figure 5: Relative importance of regressors explaining the aGvHD status. Combined data sets SRP243841, ERP105598, SRP234378 and ERP111102 - 84 patients and 178 samples.

We performed the same analysis for donor GM samples but although we seem to see an identical trend, the low number of samples available $(n=15)$ did not allow for the test to reach statistical significance, Fig. S3. Compositional differences between aGvHD cases and controls could also be documented at the species level. Using linear regression and relative importance analysis, we found that 20 taxa accounted for $51.3 \%$ (adjusted $R^{2}$ ) of the aGvHG/non-aGvHD variability, Fig. 5. The linear 
medRxiv preprint doi: https://doi.org/10.1101/2020.04.08.20058198; this version posted June 9, 2020. The copyright holder for this preprint

(which was not certified by peer review) is the author/funder, who has granted medRxiv a license to display the preprint in perpetuity.

Revised manuscript

It is made available under a CC-BY-NC-ND 4.0 International license .

model performs on the data set with a receiver operating characteristic (ROC) area under the curve (AUC) of 0.945, supplemental Fig. S4.

\section{Immuno-modulating metabolites}

Tryptophan derived aryl hydrocarbon receptor (AhR) ligands are critical for the maintenance of the intestinal epithelial barrier, and regulate innate and adaptive immunity $[37,38]$. We found the predicted relative abundance of AhR ligand tryptamine producing aromatic acid decarboxylase (padl, ec:4.1.1.28) to be decreased in GvHD, Table S1.

Polyamines, i.e. putrescine, spermidine and spermine, enforce the epithelial barrier and modulate both innate and adaptive immunity [37]. We found two putrescine producing genes, biodegradative arginine decarboxylase (adiA, ec:4.1.1.19) and agmatine ureohydrolase (speB, ec:3.5.3.11) to be predicted decreased in aGvHD as compared to non-aGvHD controls, Table S1.

Short chain fatty acids are sensed through metabolite sensor G-protein-coupled receptor 43 (GPR43), which is important for attenuation of gastrointestinal GVHD in multiple clinically relevant murine models [39]. We found the succinate pathway for propionate production [40] to be predicted more abundant in non-aGvHD controls, Table S1.

\section{In silico screening of the allo-HSCT GM}

To investigate if qualified presumption of safety (QPS) species could be of therapeutic interest, we computed pairwise $\chi^{2}$ tests for all QPS species with mortality, aGvHD case and control associated species reported above, Fig. 6. We used 21,197 samples from several tens of clinical and crowd-sourced studies as the basis for the test, TAbles 1 and S2. Supplemental Fig. S5 provides the same analysis for control associated species and Fig. S6 provides pairwise $\chi^{2}$ tests results between QPS species, the former to assess respect of control associated species and the latter to assess compatibility of QPS species for combination therapy.

The top 4 species in Fig. 6 have an unfavorable profile with regards to control associated species, Fig. S5. However, Bifidobacterium longum and Bifidobacterium breve both are in exclusion with a number of case-associated species, are complementing each other in that respect and are found in mutual inclusion (Fig. S6), hence we predict the species are compatible and can be used in a combination therapy. Bacillus clausii is found in a position similar to $B$. longum. All three species are relatively respectful non-aGvHD control associated species, Fig S5, with three or fewer co-exclusions and substantial predicted synergy with control associated species for B. longum.

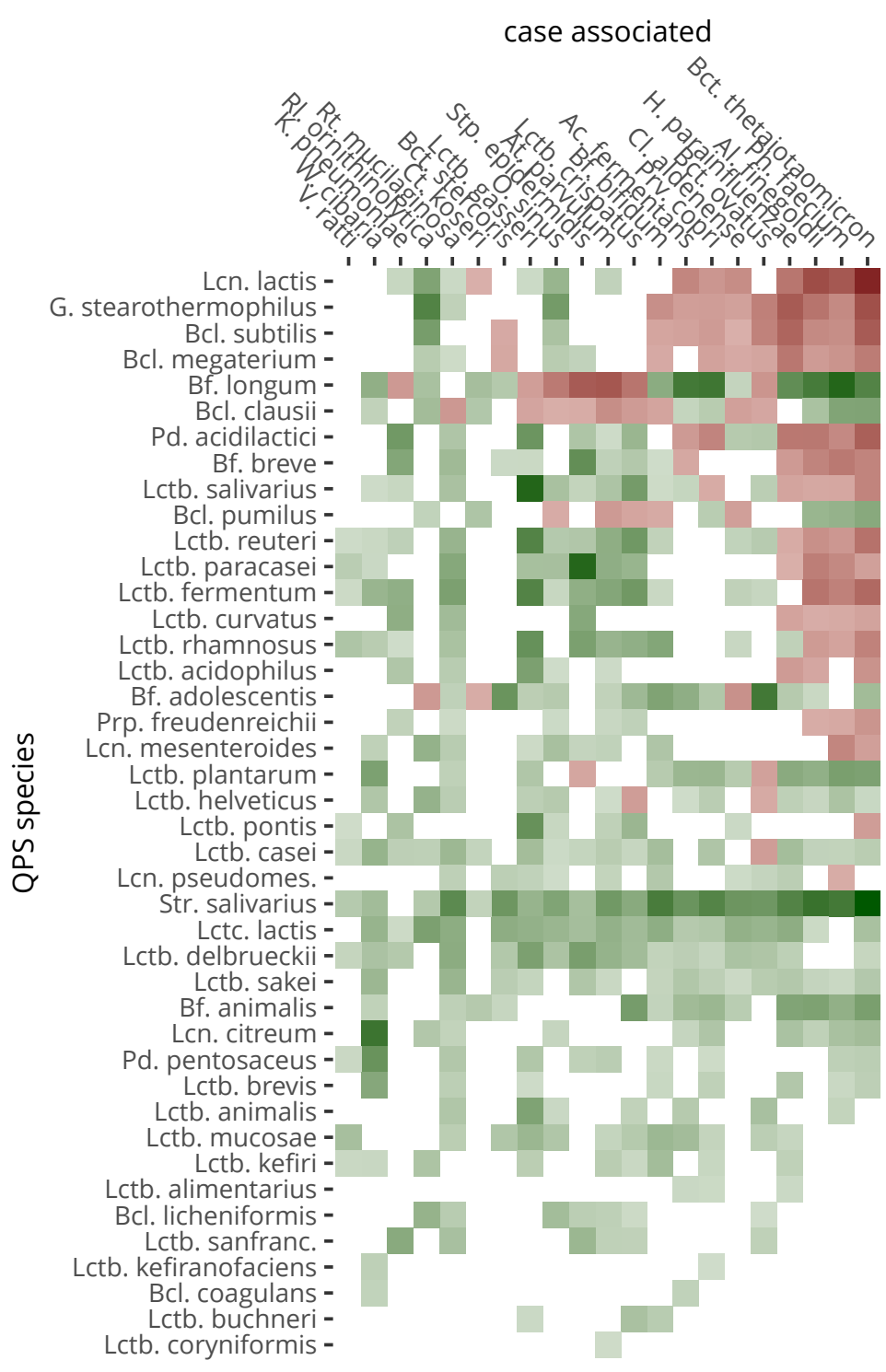

Figure 6: Co-exclusion by and co-occurrence with QPS species. Putative inhibition is in shades of red, potential synergy in shades of green. White reflect neutrality or too little combined prevalence to make a call. Genera are abbreviated as follows: Bcl.: Bacillus, Bf.: Bifidobacterium, Gb.: Geobacillus, Lcn.: Leuconostic, Lctb.: Lactobacillus, Lctc.: Lactococcus, Pd.: Pediococcus, S.: Streptococcus.

\section{Discussion}

Allo-HSCT conditioning and the GM. Our analysis of overall GM evolution across allo-HSCT shows that at baseline, i.e. after immunosuppressive conditioning, GM composition is already significantly altered, with notably decrease of strict anaerobes among which most butyrate producers are found. Cyclosporine seems to boost gram positive species, which could be beneficial in the scope of allo-HSCT, whereas its alternative tacrolimus does not. Furthermore, the latter is now known to be catabolized by intestinal Clostridia into less effective metabolites [41]. 
medRxiv preprint doi: https://doi.org/10.1101/2020.04.08.20058198; this version posted June 9, 2020. The copyright holder for this preprint

(which was not certified by peer review) is the author/funder, who has granted medRxiv a license to display the preprint in perpetuity.

Revised manuscript

It is made available under a CC-BY-NC-ND 4.0 International license .

Auto-FMT and allo-HSCT. If auto-FMT is to be practiced, the question arises when to source the samples. Sourcing after the initiation of immunosuppressive conditioning would avoid restoring butyrate producing species, which could be the safest option. GM production of butyrate benefits intestinal barrier function and decreases GvHD in a mouse model [42]. Notwithstanding this, it has been shown once aGvHD of the gut has occurred, butyrogens may impair recovery and lead to chronic GVHD [43]. Auto-FMT from our results not only restores a certain level of species diversity but also lowers the relative abundance of pathobionts as indicated by the predicted average biological safety level, which is an important feature not previously reported.

PAMPs and aGvHD. Pathogen associated molecular patterns (PAMPs) function as potent stimulators for host and donor-derived antigen presenting cells (APCS) that in turn activate and amplify the responses of alloreactive donor $T$ cells [44]. We predicted higher levels of antibiotic resistance of the GM to be associated with aGvHD cases. Increased relative abundance of resistance is associated with pathogens such as Klebsiella pneumoniae and Staphylococcus epidermidis. In addition, the efflux pumps responsible for antibiotic resistance are also capable of exporting toxic endogenous bacterial metabolites [45] which constitute potential PAMPs.

We documented the trend that high predicted BSL of the GM of allo-HSCT donors is associated with aGvHD, but more donor GM sequencing is required to demonstrate a significant correlation. Such a correlation would suggest donor antigen presenting cells or T-cells exposed to PAMPs prior to transplantation play a negative role post stemm cell infusion and that donor screening through $16 \mathrm{~S}$ sequencing could be effective in selecting donors with low PAMP exposure.

immuno-modulating metabolites. We predicted two metabolites known to influence intestinal barrier function, the AhR ligand tryptamine and the polyamine putrescine to be associated with non-aGvHD controls. In addition, we predicted a major propionate pathway to be decreased in aGvHD. Given the important difference in the GM composition between aGvHD cases and controls, many more predicted functional differences can be documented (results not shown), but these are at present relatively meaningless in the context of GvHD or allo-HSCT survival.

$T$ cells in aGvHD. Type 1 or Tc1/Th1 maturation is recognized as the dominant pattern in aGvHD and is linked to severe Gl tract pathology. Th2 differentiation causes predominantly pathology in pulmonary, hepatic, and cutaneous tissues [46]. Also, Treg/Th17 decrease has been associated with aGvHD and proposed as a biomarker $[22,47]$. Regulatory T-cell therapy for GvHD has been suggested $[48,49]$.

Mortality associated species. The H2S producer and oral commensal Atopobium parvulum is the top mor- tality associated species. It has been found involved in oral infections [50]. Importantly, it is a predominant member of the adherent microbiome of pediatric IBD patients, associated with disease severity and promotes colitis in $1110^{-/-}$mice whilst eliciting a IL-17 response [51]. The probiotic bacterium Bifidobacterium bifidum induces Th17 differentiation [52]. Clostridium aldenense has been associated with a cytokine IL-7 response [53], i.e. generic development and maintenance of T cells. Likewise, Phascolarctobacterium faecium has been found to correlate positively with immune response, i.e. IFN $\gamma^{+} \mathrm{CD}^{+} \mathrm{T}$ cells in a mouse model [54]. Acidaminococcus fermentans has been studied for its anaerobic glumate/glutamine fermentation. Glutamine has been shown to induce Treg cells in a mouse aGvHD model [55] and hence its catabolism would work against the induction of a Treg response.

All in all, the mortality associated species are associated with immune activation and an increased Th17/Treg ratio. In addition, Lactobacillus gasseri is a hydrogen peroxide producer. Although effective as an antimicrobial metabolite to control pathogens, hydrogen peroxide also functions as a damage associated molecular pattern (DAMP) in wound healing [56], which in the allo-HSCT setup could outweigh the benefits.

aGvHD case and control associated species. Staphylococcus epidermidis is the most frequently isolated species of the coagulase negative Staphylococci from human stool and can cause infection in the gut [57], including necrotizing colitis in neonates [58]. Its position as the top aGvHD associated species in our findings is unexpected, but not illogical in a context of gut decontamination, given its presence in the hospital environment and its multiple antibiotic resistance [59]. Raoultella ornithinolytica is an emerging human pathogen with betalactamase based antibiotic resistance [60]. It is closely related to the pathogen Klebsiella pneumoniae which we also found associated with aGvHD. Bacteroides ovatus has been described as the predominant commensal intestinal microbe causing a systemic antibody response in inflammatory bowel disease [61]. Rothia mucilaginosa is a oral species associated with bacteremia in patients with neutropenia and leukemia [62]. Our data suggest translocation could occur in the gut. Prevotella species are associated with a Th17 response [63], with a pro-inflammatory role for the aGvHD associated species Prevotella copri in rheumatoid arthritis [64]. Citrobacter koseri is an opportunistic nosocomial pathogen, with high propensity to initiate brain abscesses during neonatal meningitis [65]. Like LactobacilIus gasseri, Lactobacillus crispatus is a producer of hydrogen peroxide, a potential DAMP signal. The position of the commensal Bacteroides thetaiotaomicron as an aGvHD associated species is intriguing. Although commensal, its mucolytic activity makes polysaccharides available for other organisms, including pathogens [66].

The top non-GvHD control associated Bacteroides 
medRxiv preprint doi: https://doi.org/10.1101/2020.04.08.20058198; this version posted June 9, 2020. The copyright holder for this preprint

(which was not certified by peer review) is the author/funder, who has granted medRxiv a license to display the preprint in perpetuity.

Revised manuscript

It is made available under a CC-BY-NC-ND 4.0 International license .

uniformis induces IL-10 and Treg in PBMCs and LPMCs [67]. The position of Barnesiella intestihominis on the side of non-aGvHD controls is unexpected, since the bacterium has been shown to increase Th1 and decrease Treg response in cyclophosphamide anti-tumor therapy [68]. Fusicatenibacter saccharivorans has been reported decreased in active ulcerative colitis and induce IL-10 production by lamina propria mononuclear cells from not only colitis model mice but also UC patients [69]. Flavonifactor plautii has been shown to induce Treg cells in mice [70] and, importantly, the white blood cell growth factor GM-CSF in humans [53]. Lastly, we note the presence of the commensal butyrate producer Anaerostipes caccae among the non-aGvHD associated species.

The association of species with aGvHD cases and controls can be summarized as a pathogenic antibody eliciting set up on the side of the aGvHD cases and a commensal Treg cell eliciting set up on the control side.

Modulating the allo-HSCT GM. From in silico allo-HSCT GM screening results, Bifidobacterium longum seems to present potential to modulate the allo-HSCT GM. Furthermore, B. longum elicits in majority IL-10 [52]. To increase putative case associated species exclusion, $B$. longum could be combined with another probiotic species, Bifidobacterium breve, with which it is found associated in vivo more frequently than respective prevalences predict, suggesting a synergistic relation. $B$. breve induces IL-10-producing Tr1 cells in the colon [71]. Bacillus clausii, which we find in a position similar to $B$. longum from a co-exclusion perspective, also presents interest in that it has been reported to increase IL-10 in allergic children [72]. All three species are predicted to respect the non-aGvHD control associated species we documented.

A selection of a high folate producers for $B$. longum and $B$. breve could be privileged for increased Treg stimulus [73]. Combination of $B$. longum and $B$. breve with a bifidogenic prebiotic seems indicated, either choosing or avoiding the butyrigenic inulin-type fructans (ITF) or arabinoxylan-oligosaccharides (AXOS) [74], depending on the patient's aGvHD status $[42,43]$. Other than folate (vitamin B9), supplementation with vitamin $\mathrm{D}$ to compensate deficiency in allo-HSCT $[75,76]$ is worth considering.

In vitro metronidazole resistance among Bifidobacteria has been reported [77, 78]. Bifidobacteria are only moderately susceptible to the anti-gram positive vancomycin $[77,79,80]$ and to the anti-anaerobe ceftazidime but susceptible to amoxicillin [77]. Of note, a rifaximin resistant strain of $B$. longum $\mathrm{W} 11$ has been documented and is commercially available [81]. Prophylactic use of rifaximin has been shown to lower IL-6 levels [82], preserve urinary 3-IS levels and increase survival in alloHSCT as compared to ciprofloxacin/metronidazole [83]. $B$. clausii has a wide spectrum of natural antibiotic resistance, including macrolides, betalactams, aminogly- cosides, metronidazole, cefuroxime, ceftriaxone, cefotaxime and cephalosporin [84].

\section{Conclusions}

Combination of several published and unpublished data sets and use of state-of-the-art bioinformatics algorithms has allowed us to document fine grain GM composition in relation to mortality and aGvHD. This in turn allowed for the assessment of the immune status of the GM based on documented immune profiles in literature of the species involved. Using in silico prediction of exclusion of mortality and aGvHD associated species, we could formulate a probiotic composition potentially competing with these species, whilst respecting non-aGvHD control associated species.

\section{Summary}

- Immunosuppressive conditioning strength was found correlated with altered gut GM composition.

- The use of antibiotics during allo-HSCT can select resistant pathogens, which we found increased with aGvHD.

- Auto-FMT compensates bacterial diversity loss and lowers relative abundance of resistant pathogens.

- More donor stool sequencing is required to investigate the relation between aGvHD and donor exposure to pathobionts.

- Mortality and aGvHD associated species are predicted to elicit Th17 response whereas non-aGvHD control associated species are predicted to elicit a Treg response.

- B. longum and B. breve are predicted to compete with mortality and aGvHD associated species whilst respecting non-aGvHD control associated species.

- Antibiotics use can be tuned to correspond with Bifidobacterial resistance such that prophylactic supplementation during the antibiotics course becomes possible.

- Prebiotics and vitamins B9 and D can further enhance the prophylactic use of a supplement based on $B$. longum and B. breve.

\section{Declarations}

Acknowledgements. The authors acknowledge the contributions to the Short Read Archive made by the respective institutions and acknowledge scientific journals for enforcing this practice.

Financial \& competing interest disclosure. The authors are co-founders of and own shares in GeneCreek, Inc. Other than that, the authors declare no relevant affiliations or financial involvement with any organization or entity with a financial interest in or financial conflict with the subject matter or materials discussed in the 
medRxiv preprint doi: https://doi.org/10.1101/2020.04.08.20058198; this version posted June 9, 2020. The copyright holder for this preprint

(which was not certified by peer review) is the author/funder, who has granted medRxiv a license to display the preprint in perpetuity.

Revised manuscript It is made available under a CC-BY-NC-ND 4.0 International license .

manuscript. This includes employment, consultancies, honoraria, expert testimony, grants or patents received or pending, or royalties.

No writing assistance was utilized in the production of this manuscript.

Ethical conduct of research. The authors declare that no human or animal experimental investigations have been carried out.

\section{Bibliography}

[1] Ying Taur, Katharine Coyte, Jonas Schluter, Elizabeth Robilotti, Cesar Figueroa, Mergim Gjonbalaj, Eric R Littmann, Lilan Ling, Liza Miller, Yangtsho Gyaltshen, Emily Fontana, Sejal Morjaria, Boglarka Gyurkocza, Miguel-Angel Perales, Hugo CastroMalaspina, Roni Tamari, Doris Ponce, Guenther Koehne, Juliet Barker, Ann Jakubowski, Esperanza Papadopoulos, Parastoo Dahi, Craig Sauter, Brian Shaffer, James W Young, Jonathan Peled, Richard C Meagher, Robert R Jenq, Marcel R M van den Brink, Sergio A Giralt, Eric G Pamer, and Joao B Xavier. Reconstitution of the gut microbiota of antibiotictreated patients by autologous fecal microbiota transplant. Science Translational Medicine, 10 (460), September 2018. doi: 10.1126/scitranslmed. aap9489.

[2] C Liu, D N Frank, M Horch, S Chau, D Ir, E A Horch, $\mathrm{K}$ Tretina, $\mathrm{K}$ van Besien, $\mathrm{C}$ A Lozupone, and $\mathrm{V} \mathrm{H}$ Nguyen. Associations between acute gastrointestinal GvHD and the baseline gut microbiota of allogeneic hematopoietic stem cell transplant recipients and donors. Bone marrow transplantation, 52(12):1643-1650, December 2017. doi: 10.1038/ bmt.2017.200.

[3] Elena Biagi, Daniele Zama, Simone Rampelli, Silvia Turroni, Patrizia Brigidi, Clarissa Consolandi, Marco Severgnini, Eleonora Picotti, Pietro Gasperini, Pietro Merli, Nunzia Decembrino, Marco Zecca, Simone Cesaro, Maura Faraci, Arcangelo Prete, Franco Locatelli, Andrea Pession, Marco Candela, and Riccardo Masetti. Early gut microbiota signature of aGvHD in children given allogeneic hematopoietic cell transplantation for hematological disorders. $B M C$ medical genomics, 12(1):49-11, March 2019. doi: 10.1186/s12920-019-0494-7.

[4] Federica D'Amico, Elena Biagi, Simone Rampelli, Jessica Fiori, Daniele Zama, Matteo Soverini, Monica Barone, Davide Leardini, Edoardo Muratore, Arcangelo Prete, Roberto Gotti, Andrea Pession, Riccardo Masetti, Patrizia Brigidi, Silvia Turroni, and Marco Candela. Enteral Nutrition in Pediatric Patients Undergoing Hematopoietic SCT Promotes the Recovery of Gut Microbiome Homeostasis. Nu- trients, 11(12), December 2019. doi: 10.3390/ nu11122958.

[5] Vincent Bekker, Romy D Zwittink, Cornelis W Knetsch, Ingrid M J G Sanders, Dagmar Berghuis, Peter J Heidt, Jaak M J J Vossen, Willem M de Vos, Clara Belzer, Robbert G M Bredius, Peter J Van't Hof, Arjan C Lankester, and Ed J Kuijper. Dynamics of the Gut Microbiota in Children Receiving Selective or Total Gut Decontamination Treatment during Hematopoietic Stem Cell Transplantation. Biology of blood and marrow transplantation: journal of the American Society for Blood and Marrow Transplantation, 25(6):1164-1171, June 2019. doi: 10.1016/j.bbmt.2019.01.037.

[6] John Magenau, Lyndsey Runaas, and Pavan Reddy. Advances in understanding the pathogenesis of graft-versus-host disease. British journal of haematology, 173(2):190-205, April 2016. doi: 10.1111/ bjh.13959.

[7] G R Hill, J M Crawford, K R Cooke, Y S Brinson, L Pan, and J L Ferrara. Total body irradiation and acute graft-versus-host disease: the role of gastrointestinal damage and inflammatory cytokines. Blood, 90 (8):3204-3213, October 1997. doi: 10.1182/blood. V90.8.3204.

[8] Yusuke Shono, Melissa D Docampo, Jonathan U Peled, Suelen M Perobelli, Enrico Velardi, Jennifer J Tsai, Ann E Slingerland, Odette M Smith, Lauren F Young, Jyotsna Gupta, Sophia R Lieberman, Hillary V Jay, Katya F Ahr, Kori A Porosnicu Rodriguez, Ke Xu, Marco Calarfiore, Hendrik Poeck, Silvia Caballero, Sean M Devlin, Franck Rapaport, Jarrod A Dudakov, Alan M Hanash, Boglarka Gyurkocza, George F Murphy, Camilla Gomes, Chen Liu, Eli L Moss, Shannon B Falconer, Ami S Bhatt, Ying Taur, Eric G Pamer, Marcel R M van den Brink, and Robert R Jenq. Increased GVHD-related mortality with broad-spectrum antibiotic use after allogeneic hematopoietic stem cell transplantation in human patients and mice. Science Translational Medicine, 8(339):339ra71-339ra71, May 2016. doi: 10.1126/scitransImed.aaf2311.

[9] Daniela Weber, Andreas Hiergeist, Markus Weber, Katja Dettmer, Daniel Wolff, Joachim Hahn, Wolfgang Herr, André Gessner, and Ernst Holler. Detrimental Effect of Broad-spectrum Antibiotics on Intestinal Microbiome Diversity in Patients After Allogeneic Stem Cell Transplantation: Lack of Commensal Sparing Antibiotics. Clinical infectious diseases : an official publication of the Infectious Diseases Society of America, 68(8):1303-1310, April 2019. doi: $10.1093 /$ cid/ciy711.

[10] D W Beelen, A Elmaagacli, K D Müller, H Hirche, and $U$ W Schaefer. Influence of intestinal bacterial decontamination using metronidazole and 
medRxiv preprint doi: https://doi.org/10.1101/2020.04.08.20058198; this version posted June 9, 2020. The copyright holder for this preprint

(which was not certified by peer review) is the author/funder, who has granted medRxiv a license to display the preprint in perpetuity.

Revised manuscript It is made available under a CC-BY-NC-ND 4.0 International license .

ciprofloxacin or ciprofloxacin alone on the development of acute graft-versus-host disease after marrow transplantation in patients with hematologic malignancies: final results and long-term followup of an open-label prospective randomized trial. Blood, 93(10):3267-3275, May 1999. doi: 10.1182/ blood.V93.10.3267.410k22_3267_3275.

[11] Jaak M Vossen, Harry F L Guiot, Arjan C Lankester, Ann C T M Vossen, Robbert G M Bredius, Ron Wolterbeek, Hanny D J Bakker, and Peter J Heidt. Complete suppression of the gut microbiome prevents acute graft-versus-host disease following allogeneic bone marrow transplantation. PLOS ONE, 9(9), 2014. doi: 10.1371/journal.pone.0105706.

[12] Zachariah DeFilipp, Jonathan U Peled, Shuli Li, Jasmin Mahabamunuge, Zeina Dagher, Ann E Slingerland, Candice Del Rio, Betsy Valles, Maria E Kempner, Melissa Smith, Jami Brown, Bimalangshu R Dey, Areej El-Jawahri, Steven L McAfee, Thomas R Spitzer, Karen K Ballen, Anthony D Sung, Tara E Dalton, Julia A Messina, Katja Dettmer, Gerhard Liebisch, Peter Oefner, Ying Taur, Eric G Pamer, Ernst Holler, Michael K Mansour, Marcel R M van den Brink, Elizabeth Hohmann, Robert R Jenq, and Yi-Bin Chen. Third-party fecal microbiota transplantation following allo-HCT reconstitutes microbiome diversity. Blood advances, 2(7):745753, April 2018. doi: 10.1182/bloodadvances. 2018017731.

[13] Emmanuel Montassier, Eric Batard, Sébastien Massart, Thomas Gastinne, Thomas Carton, Jocelyne Caillon, Sophie Le Fresne, Nathalie Caroff, Jean Benoit Hardouin, Philippe Moreau, Gilles Potel, Françoise Le Vacon, and Marie France de La Cochetière. 16S rRNA Gene Pyrosequencing Reveals Shift in Patient Faecal Microbiota During High-Dose Chemotherapy as Conditioning Regimen for Bone Marrow Transplantation. Microbial Ecology, 67(3):690-699, April 2014. doi: 10.1007/ s00248-013-0355-4.

[14] Giorgia Battipaglia, Florent Malard, Marie Therèse Rubio, Annalisa Ruggeri, Anne Claire Mamez, Eolia Brissot, Federica Giannotti, Remy Dulery, Anne Christine Joly, Minh Tam Baylatry, Marie Jeanne Kossmann, Jacques Tankovic, Laurent Beaugerie, Harry Sokol, and Mohamad Mohty. Fecal microbiota transplantation before or after allogeneic hematopoietic transplantation in patients with hematologic malignancies carrying multidrug-resistance bacteria. Haematologica, 104(8):1682-1688, August 2019. doi: 10.3324/haematol.2018.198549.

[15] Kazuhiko Kakihana, Yuki Fujioka, Wataru Suda, Yuho Najima, Go Kuwata, Satoshi Sasajima, lyo
Mimura, Hidetoshi Morita, Daisuke Sugiyama, Hiroyoshi Nishikawa, Masahira Hattori, Yutaro Hino, Shuntaro Ikegawa, Keita Yamamoto, Takashi Toya, Noriko Doki, Koichi Koizumi, Kenya Honda, and Kazuteru Ohashi. Fecal microbiota transplantation for patients with steroid-resistant acute graft-versus-host disease of the gut. Blood, 128 (16):2083-2088, October 2016. doi: 10.1182/ blood-2016-05-717652.

[16] Kazuhiko Kakihana. Fecal microbiota transplantation for acute graft-versus-host disease of the gut. The Japanese journal of clinical hematology, 58(5): 499-505, 2017. doi: 10.11406/rinketsu.58.499.

[17] Walter Spindelboeck, Eduard Schulz, Barbara Uhl, Karl Kashofer, Ariane Aigelsreiter, Wilma ZinkeCerwenka, Adnan Mulabecirovic, Patrizia K Kump, Bettina Halwachs, Gregor Gorkiewicz, Heinz Sill, Hildegard Greinix, Christoph Högenauer, and Peter Neumeister. Repeated fecal microbiota transplantations attenuate diarrhea and lead to sustained changes in the fecal microbiota in acute, refractory gastrointestinal graft-versus-host-disease. Haematologica, 102(5):e210-e213, May 2017. doi: 10.3324/haematol.2016.154351.

[18] Xiaofei Qi, Xuewei Li, Ye Zhao, Xiaojin Wu, Feng Chen, Xiao Ma, Faming Zhang, and Depei Wu. Treating Steroid Refractory Intestinal Acute Graftvs.-Host Disease With Fecal Microbiota Transplantation: A Pilot Study. Frontiers in immunology, 9: 2195, 2018. doi: 10.3389/fimmu.2018.02195.

[19] Eric G. Pamer, Ying Taur, Robert Jenq, and Marcel R.M. van den Brink. Impact of the Intestinal Microbiota on Infections and Survival Following Hematopoietic Stem Cell Transplantation. Blood, 21(124), December 2014. doi: 10.1182/blood.V124. 21.SCl-48.SCl-48.

[20] Ying Taur, Robert R Jenq, Miguel-Angel Perales, Eric R Littmann, Sejal Morjaria, Lilan Ling, Daniel No, Asia Gobourne, Agnes Viale, Parastoo B Dahi, Doris M Ponce, Juliet N Barker, Sergio Giralt, Marcel van den Brink, and Eric G Pamer. The effects of intestinal tract bacterial diversity on mortality following allogeneic hematopoietic stem cell transplantation. Blood, 124(7):1174-1182, August 2014. doi: 10.1182/blood-2014-02-554725.

[21] Jonathan L Golob, Steven A Pergam, Sujatha Srinivasan, Tina L Fiedler, Congzhou Liu, Kristina Garcia, Marco Mielcarek, Daisy Ko, Sarah Aker, Sara Marquis, Tillie Loeffelholz, Anna Plantinga, Michael C Wu, Kevin Celustka, Alex Morrison, Maresa Woodfield, and David N Fredricks. Stool Microbiota at Neutrophil Recovery Is Predictive for Severe Acute Graft vs Host Disease After Hematopoietic Cell 
medRxiv preprint doi: https://doi.org/10.1101/2020.04.08.20058198; this version posted June 9, 2020. The copyright holder for this preprint

(which was not certified by peer review) is the author/funder, who has granted medRxiv a license to display the preprint in perpetuity.

Revised manuscript It is made available under a CC-BY-NC-ND 4.0 International license .

Transplantation. Clinical infectious diseases : an official publication of the Infectious Diseases Society of America, 65(12):1984-1991, November 2017. doi: $10.1093 / \mathrm{cid} / \mathrm{cix} 699$.

[22] Lijie Han, Hua Jin, Lizhi Zhou, Xin Zhang, Zhiping Fan, Min Dai, Qianyun Lin, Fen Huang, Li Xuan, Haiyan Zhang, and Qifa Liu. Intestinal Microbiota at Engraftment Influence Acute Graft-Versus-Host Disease via the Treg/Th17 Balance in Allo-HSCT Recipients. Frontiers in immunology, 9:669, 2018. doi: 10.3389/fimmu.2018.00669.

[23] Jessica R Galloway-Peña, Christine B Peterson, Farida Malik, Pranoti V Sahasrabhojane, Dimpy $P$ Shah, Chelcy E Brumlow, Lily G Carlin, Roy F Chemaly, Jin Seon Im, Gabriela Rondon, Edd Felix, Lucas Veillon, Philip L Lorenzi, Amin M Alousi, Robert R Jenq, Dimitrios P Kontoyiannis, Elizabeth J Shpall, Samuel A Shelburne, and Pablo C Okhuysen. Fecal Microbiome, Metabolites, and Stem Cell Transplant Outcomes: A Single-Center Pilot Study. Open forum infectious diseases, 6(5):ofz173, May 2019. doi: 10.1093/ofid/ofz173.

[24] Jonathan U Peled, Antonio L C Gomes, Sean M Devlin, Eric R Littmann, Ying Taur, Anthony D Sung, Daniela Weber, Daigo Hashimoto, Ann E Slingerland, John B Slingerland, Molly Maloy, Annelie G Clurman, Christoph K Stein-Thoeringer, Kate A Markey, Melissa D Docampo, Marina Burgos da Silva, Niloufer Khan, André Gessner, Julia A Messina, Kristi Romero, Meagan V Lew, Amy Bush, Lauren Bohannon, Daniel G Brereton, Emily Fontana, Luigi A Amoretti, Roberta J Wright, Gabriel K Armijo, Yusuke Shono, Míriam Sanchez-Escamilla, Nerea Castillo Flores, Ana Alarcon Tomas, Richard J Lin, Lucrecia Yáñez San Segundo, Gunjan L Shah, Christina Cho, Michael Scordo, Ioannis Politikos, Kasumi Hayasaka, Yuta Hasegawa, Boglarka Gyurkocza, Doris M Ponce, Juliet N Barker, Miguel-Angel Perales, Sergio A Giralt, Robert R Jenq, Takanori Teshima, Nelson J Chao, Ernst Holler, Joao B Xavier, Eric G Pamer, and Marcel R M van den Brink. Microbiota as Predictor of Mortality in Allogeneic HematopoieticCell Transplantation. The New England journal of medicine, 382(9):822-834, February 2020. doi: 10. 1056/NEJMoa1900623.

[25] Ernst Holler, Peter Butzhammer, Karin Schmid, Christian Hundsrucker, Josef Koestler, Katrin Peter, Wentao Zhu, Daniela Sporrer, Thomas Hehlgans, Marina Kreutz, Barbara Holler, Daniel Wolff, Matthias Edinger, Reinhard Andreesen, John E Levine, James L Ferrara, André Gessner, Rainer Spang, and Peter J Oefner. Metagenomic analysis of the stool microbiome in patients receiving allogeneic stem cell transplantation: loss of diversity is associated with use of systemic antibiotics and more pronounced in gastrointestinal graft-versushost disease. Biology of blood and marrow transplantation : journal of the American Society for Blood and Marrow Transplantation, 20(5):640-645, May 2014. doi: 10.1016/j.bbmt.2014.01.030.

[26] C K Stein-Thoeringer, K B Nichols, A Lazrak, M D Docampo, A E Slingerland, J B Slingerland, A G Clurman, G Armijo, A L C Gomes, Y Shono, A Staffas, M Burgos da Silva, S M Devlin, K A Markey, D Bajic, R Pinedo, A Tsakmaklis, E R Littmann, A Pastore, Y Taur, S Monette, M E Arcila, A J Pickard, M Maloy, R J Wright, L A Amoretti, E Fontana, D Pham, M A Jamal, D Weber, A D Sung, D Hashimoto, C Scheid, J B Xavier, J A Messina, K Romero, M Lew, A Bush, L Bohannon, K Hayasaka, Y Hasegawa, M J G T Vehreschild, J R Cross, D M Ponce, M A Perales, S A Giralt, R R Jenq, T Teshima, E Holler, N J Chao, E G Pamer, J U Peled, and M R M van den Brink. Lactose drives Enterococcus expansion to promote graft-versus-host disease. Science, 366 (6469):1143-1149, November 2019. doi: 10.1126/ science.aax3760.

[27] Robert R Jenq, Ying Taur, Sean M Devlin, Doris M Ponce, Jenna D Goldberg, Katya F Ahr, Eric R Littmann, Lilan Ling, Asia C Gobourne, Liza C Miller, Melissa D Docampo, Jonathan U Peled, Nicholas Arpaia, Justin R Cross, Tatanisha K Peets, Melissa A Lumish, Yusuke Shono, Jarrod A Dudakov, Hendrik Poeck, Alan M Hanash, Juliet N Barker, MiguelAngel Perales, Sergio A Giralt, Eric G Pamer, and Marcel R M van den Brink. Intestinal Blautia Is Associated with Reduced Death from Graft-versus-Host Disease. Biology of blood and marrow transplantation : journal of the American Society for Blood and Marrow Transplantation, 21(8):1373-1383, August 2015. doi: 10.1016/j.bbmt.2015.04.016.

[28] McMurdie, Paul J, Rosen, Michael J, Han, Andrew W, Johnson, Amy Jo A, Holmes, Susan P, and Callahan, Benjamin J. DADA2: High-resolution sample inference from Illumina amplicon data. Nature Methods, pages 1-7, May 2016. doi: 10.1038/nmeth.3869.

[29] Ben J Callahan, Kris Sankaran, Julia A Fukuyama, Paul J McMurdie, and Susan P Holmes. Bioconductor Workflow for Microbiome Data Analysis: from raw reads to community analyses. F1000Research, 5, 2016. doi: 10.12688/f1000research.8986.2.

[30] Kazutaka Katoh, George Asimenos, and Hiroyuki Toh. Multiple alignment of DNA sequences with MAFFT. Methods in molecular biology (Clifton, N.J.), 537(Suppl 5):39-64, 2009. doi: 10.1007/ 978-1-59745-251-9_3.

[31] Price, Morgan N, Dehal, Paramvir S, and Arkin, Adam P. FastTree 2-approximately maximumlikelihood trees for large alignments. PLOS ONE, 5 
medRxiv preprint doi: https://doi.org/10.1101/2020.04.08.20058198; this version posted June 9, 2020. The copyright holder for this preprint

(which was not certified by peer review) is the author/funder, who has granted medRxiv a license to display the preprint in perpetuity.

Revised manuscript It is made available under a CC-BY-NC-ND 4.0 International license .

(3):e9490, March 2010. doi: 10.1371/journal.pone. 0009490.

[32] Lorenz Christian Reimer, Anna Vetcininova, Joaquim Sardà Carbasse, Carola Söhngen, Dorothea Gleim, Christian Ebeling, and Jörg Overmann. BacDive in 2019: bacterial phenotypic data for High-throughput biodiversity analysis. Nucleic acids research, 47(D1):D631-D636, January 2019. doi: 10.1093/nar/gky879.

[33] Albert Barberán, Hildamarie Caceres Velazquez, Stuart Jones, Noah Fierer, and Steven J Hallam. Hiding in Plain Sight: Mining Bacterial Species Records for Phenotypic Trait Information. mSphere, 2(4): e00237-17, August 2017. doi: 10.1128/mSphere. 00237-17.

[34] Groemping, Ulrike. Relative Importance for Linear Regression in R: The Package relaimpo. Journal of Statistical Software, 17(1):1-27, September 2006. doi: 10.18637/jss.v017.i01.

[35] Steven F Stoddard, Byron J Smith, Robert Hein, Benjamin R K Roller, and Thomas M Schmidt. rrnDB: improved tools for interpreting rRNA gene abundance in bacteria and archaea and a new foundation for future development. Nucleic acids research, 43(Database issue):D593-8, January 2015. doi: 10.1093/nar/gku1201.

[36] The UniProt Consortium. UniProt: a worldwide hub of protein knowledge. Nucleic acids research, 47(D1):D506-D515, January 2019. doi: 10.1093/ nar/gky1049.

[37] M Riwes and P Reddy. Microbial metabolites and graft versus host disease. American journal of transplantation, 18(1):23-29, January 2018. doi: 10. 1111/ajt.14443.

[38] David Michonneau, Eleonora Latis, Emmanuel Curis, Laetitia Dubouchet, Sivapriya Ramamoorthy, Brian Ingram, Régis Peffault de Latour, Marie Robin, Flore Sicre de Fontbrune, Sylvie Chevret, Lars Rogge, and Gérard Socié. Metabolomics analysis of human acute graft-versus-host disease reveals changes in host and microbiotaderived metabolites. Nature communications, 10 (1):5695-15, December 2019. doi: 10.1038/ s41467-019-13498-3.

[39] Hideaki Fujiwara, Melissa D Docampo, Mary Riwes, Daniel Peltier, Tomomi Toubai, Israel Henig, S Julia Wu, Stephanie Kim, Austin Taylor, Stuart Brabbs, Chen Liu, Cynthia Zajac, Katherine Oravecz-Wilson, Yaping Sun, Gabriel Núñez, John E Levine, Marcel $\mathrm{R} M$ van den Brink, James L M Ferrara, and Pavan Reddy. Microbial metabolite sensor GPR43 controls severity of experimental GVHD. Nature communications, 9(1):3674-15, September 2018. doi: 10.1038/s41467-018-06048-w.
[40] Petra Louis and Harry J Flint. Formation of propionate and butyrate by the human colonic microbiota. Environmental Microbiology, 19(1):29-41, January 2017. doi: 10.1111/1462-2920.13589.

[41] Yukuang Guo, Camila Manoel Crnkovic, KyoungJae Won, Xiaotong Yang, John Richard Lee, Jimmy Orjala, Hyunwoo Lee, and Hyunyoung Jeong. Commensal Gut Bacteria Convert the Immunosuppressant Tacrolimus to Less Potent Metabolites. Drug Metabolism and Disposition, 47(3):194-202, March 2019. doi: 10.1124/dmd.118.084772.

[42] Nathan D Mathewson, Robert Jenq, Anna V Mathew, Mark Koenigsknecht, Alan Hanash, Tomomi Toubai, Katherine Oravecz-Wilson, ShinRong Wu, Yaping Sun, Corinne Rossi, Hideaki Fujiwara, Jaeman Byun, Yusuke Shono, Caroline Lindemans, Marco Calafiore, Thomas M Schmidt, Kenya Honda, Vincent B Young, Subramaniam Pennathur, Marcel van den Brink, and Pavan Reddy. Gut microbiome-derived metabolites modulate intestinal epithelial cell damage and mitigate graftversus-host disease. Nature Immunology, 17(5): 505-513, May 2016. doi: 10.1038/ni.3400.

[43] Jonathan L Golob, Martha M DeMeules, Tillie Loeffelholz, Z Z Quinn, Michael K Dame, Sabrina S Silvestri, Michael $C W u$, Thomas M Schmidt, Tina $L$ Fiedler, Matthew J Hoostal, Marco Mielcarek, Jason Spence, Steven A Pergam, and David N Fredricks. Butyrogenic bacteria after acute graft-versus-host disease (GVHD) are associated with the development of steroid-refractory GVHD. Blood advances, 3(19):2866-2869, October 2019. doi: 10.1182/ bloodadvances.2019000362.

[44] Tomomi Toubai, Nathan D Mathewson, John Magenau, and Pavan Reddy. Danger Signals and Graftversus-host Disease: Current Understanding and Future Perspectives. Frontiers in immunology, 7(3): 539, 2016. doi: 10.3389/fimmu.2016.00539.

[45] Paula Blanco, Sara Hernando-Amado, Jose Antonio Reales-Calderon, Fernando Corona, Felipe Lira, Manuel Alcalde-Rico, Alejandra Bernardini, Maria Blanca Sanchez, and José-Luis Martinez. Bacterial Multidrug Efflux Pumps: Much More Than Antibiotic Resistance Determinants. Microorganisms, 4(1):14, February 2016. doi: 10.3390/ microorganisms4010014.

[46] Andrea S Henden and Geoffrey R Hill. Cytokines in Graft-versus-Host Disease. Journal of immunology (Baltimore, Md. : 1950), 194(10):4604-4612, May 2015. doi: 10.4049/jimmunol.1500117.

[47] Yuejun Liu, Yifeng Cai, Lan Dai, Guanghua Chen, Xiao Ma, Ying Wang, Ting Xu, Song Jin, Xiaojin Wu, Huiying Qiu, Xiaowen Tang, Caixia Li, Aining Sun, 
medRxiv preprint doi: https://doi.org/10.1101/2020.04.08.20058198; this version posted June 9, 2020. The copyright holder for this preprint

(which was not certified by peer review) is the author/funder, who has granted medRxiv a license to display the preprint in perpetuity.

Revised manuscript It is made available under a CC-BY-NC-ND 4.0 International license .

Depei Wu, and Haiyan Liu. The expression of Th17associated cytokines in human acute graft-versushost disease. Biology of blood and marrow transplantation : journal of the American Society for Blood and Marrow Transplantation, 19(10):1421-1429, October 2013. doi: 10.1016/j.bbmt.2013.06.013.

[48] Jessica Heinrichs, David Bastian, Anandharaman Veerapathran, Claudio Anasetti, Brain Betts, and Xue-Zhong Yu. Regulatory T-Cell Therapy for Graftversus-host Disease. Journal of immunology research and therapy, 1(1):1-14, 2016.

[49] Shlomo Elias and Alexander Y Rudensky. Therapeutic use of regulatory $T$ cells for graft-versushost disease. British journal of haematology, 187(1): 25-38, October 2019. doi: 10.1111/bjh.16157.

[50] Julia Downes, Mark A Munson, David A Spratt, Eija Könönen, Eveliina Tarkka, Hannele JousimiesSomer, and William G Wade. Characterisation of Eubacterium-like strains isolated from oral infections. Journal of medical microbiology, 50 (11):947-951, November 2001. doi: 10.1099/ 0022-1317-50-11-947.

[51] Marcus Muehlbauer, Walid Mottawea, Turki Abujamel, David R Mack, Alain Stintzi, and Christian Jobin. Atopobium Parvulum Is a Predominant Member of the Adherent Microbiome of Pediatric IBD Patients and Promotes Colitis in II10-/- Mice. Gastroenterology, 144(5):S-710, May 2013. doi: 10. 1016/S0016-5085(13)62634-7.

[52] Patricia López, Irene González-Rodríguez, Miguel Gueimonde, Abelardo Margolles, and Ana Suárez. Immune response to Bifidobacterium bifidum strains support Treg/Th17 plasticity. PLOS ONE, 6 (9), 2011. doi: 10.1371/journal.pone.0024776.

[53] Ruth Ann Luna, Numan Oezguen, Miriam Balderas, Alamelu Venkatachalam, Jessica K Runge, James Versalovic, Jeremy Veenstra-VanderWeele, George M Anderson, Tor Savidge, and Kent C Williams. Distinct Microbiome-Neuroimmune Signatures Correlate With Functional Abdominal Pain in Children With Autism Spectrum Disorder. Cellular and molecular gastroenterology and hepatology, 3(2):218-230, March 2017. doi: 10.1016/j.jcmgh.2016.11.008.

[54] Takeshi Tanoue, Satoru Morita, Damian R Plichta, Ashwin N Skelly, Wataru Suda, Yuki Sugiura, Seiko Narushima, Hera Vlamakis, Iori Motoo, Kayoko Sugita, Atsushi Shiota, Kozue Takeshita, Keiko Yasuma-Mitobe, Dieter Riethmacher, Tsuneyasu Kaisho, Jason M Norman, Daniel Mucida, Makoto Suematsu, Tomonori Yaguchi, Vanni Bucci, Takashi Inoue, Yutaka Kawakami, Bernat Olle, Bruce Roberts, Masahira Hattori, Ramnik J Xavier, Koji
Atarashi, and Kenya Honda. A defined commensal consortium elicits CD8 T cells and anti-cancer immunity. Nature, 565(7741):600-605, January 2019. doi: 10.1038/s41586-019-0878-z.

[55] Eun-Kee Song, Jun-Mo Yim, Joo-Yun Yim, MinYoung Song, Hye-Won Rho, Sung Kyun Yim, YeonHee Han, So Yeon Jeon, Hee Sun Kim, Ho-Young Yhim, Na-Ri Lee, Jae-Yong Kwak, Myung-Hee Sohn, Ho Sung Park, Kyu Yun Jang, and Chang-Yeol Yim. Glutamine protects mice from acute graft-versushost disease (aGVHD). Biochemical and Biophysical Research Communications, 435(1):94-99, May 2013. doi: 10.1016/j.bbrc.2013.04.047.

[56] Albert van der Vliet and Yvonne M W JanssenHeininger. Hydrogen peroxide as a damage signal in tissue injury and inflammation: murderer, mediator, or messenger? Journal of cellular biochemistry, 115(3):427-435, March 2014. doi: 10.1002/ jcb.24683.

[57] Ezekiel Olugbenga Akinkunmi, Oluwole Isaac Adeyemi, Oluwatoyin Abimbola Igbeneghu, Esther Omowunmi Olaniyan, Abidemi Emmanuel Omonisi, and Adebayo Lamikanra. The pathogenicity of Staphylococcus epidermidis on the intestinal organs of rats and mice: an experimental investigation. BMC gastroenterology, 14(1): 126-8, July 2014. doi: 10.1186/1471-230X-14-126.

[58] Ying Dong, Christian P Speer, and Kirsten Glaser. Beyond sepsis: Staphylococcus epidermidis is an underestimated but significant contributor to neonatal morbidity. Virulence, 9(1):621-633, January 2018. doi: 10.1080/21505594.2017.1419117.

[59] Roya Chabi and Hassan Momtaz. Virulence factors and antibiotic resistance properties of the Staphylococcus epidermidis strains isolated from hospital infections in Ahvaz, Iran. Tropical medicine and health, 47(1):56-9, 2019. doi: 10.1186/ s41182-019-0180-7.

[60] Roy Hajjar, Georges Ambaraghassi, Herawaty Sebajang, Frank Schwenter, and Shih-Hann Su. Raoultella ornithinolytica: Emergence and Resistance. Infection and Drug Resistance, 13:1091-1104, 2020. doi: 10.2147/IDR.S191387.

[61] Shin Saitoh, Satoshi Noda, Yuji Aiba, Atsushi Takagi, Mitsuo Sakamoto, Yoshimi Benno, and Yasuhiro Koga. Bacteroides ovatus as the predominant commensal intestinal microbe causing a systemic antibody response in inflammatory bowel disease. Clinical and diagnostic laboratory immunology, 9(1): 54-59, January 2002. doi: 10.1128/CDLI.9.1.54-59. 2002.

[62] Poornima Ramanan, Jason N Barreto, Douglas $R$ Osmon, and Pritish K Tosh. Rothia bacteremia: 
medRxiv preprint doi: https://doi.org/10.1101/2020.04.08.20058198; this version posted June 9, 2020. The copyright holder for this preprint

(which was not certified by peer review) is the author/funder, who has granted medRxiv a license to display the preprint in perpetuity.

Revised manuscript It is made available under a CC-BY-NC-ND 4.0 International license .

a 10-year experience at Mayo Clinic, Rochester, Minnesota. Journal of clinical microbiology, 52(9): 3184-3189, September 2014. doi: 10.1128/JCM. 01270-14.

[63] Jeppe Madura Larsen. The immune response to Prevotella bacteria in chronic inflammatory disease. Immunology, 151(4):363-374, August 2017. doi: $10.1111 / \mathrm{imm} .12760$.

[64] Jose U Scher, Andrew Sczesnak, Randy S Longman, Nicola Segata, Carles Ubeda, Craig Bielski, Tim Rostron, Vincenzo Cerundolo, Eric G Pamer, Steven B Abramson, Curtis Huttenhower, and Dan R Littman. Expansion of intestinal Prevotella copri correlates with enhanced susceptibility to arthritis. elife, 2:e01202, November 2013. doi: 10.7554/eLife.01202.

[65] Stacy M Townsend, Harvey A Pollack, Ignacio Gonzalez-Gomez, Hiroyuki Shimada, and Julie L Badger. Citrobacter koseri brain abscess in the neonatal rat: survival and replication within human and rat macrophages. Infection and Immunity, 71(10):5871-5880, October 2003. doi: 10.1128/iai. 71.10.5871-5880.2003.

[66] Meredith M Curtis, Zeping Hu, Claire Klimko, Sanjeev Narayanan, Ralph Deberardinis, and Vanessa Sperandio. The gut commensal Bacteroides thetaiotaomicron exacerbates enteric infection through modification of the metabolic landscape. Cell host \& microbe, 16(6):759-769, December 2014. doi: 10.1016/j.chom.2014.11.005.

[67] C Preston Neff, Matthew E Rhodes, Kathleen L Arnolds, Colm B Collins, Jody Donnelly, Nichole Nusbacher, Paul Jedlicka, Jennifer M Schneider, Martin D McCarter, Michael Shaffer, Sarkis K Mazmanian, Brent E Palmer, and Catherine A Lozupone. Diverse Intestinal Bacteria Contain Putative Zwitterionic Capsular Polysaccharides with Anti-inflammatory Properties. Cell host \& microbe, 20(4):535-547, October 2016. doi: 10.1016/j.chom. 2016.09.002.

[68] Romain Daillère, Marie Vétizou, Nadine Waldschmitt, Takahiro Yamazaki, Christophe Isnard, Vichnou Poirier-Colame, Connie P M Duong, Caroline Flament, Patricia Lepage, Maria Paula Roberti, Bertrand Routy, Nicolas Jacquelot, Lionel Apetoh, Sonia Becharef, Sylvie Rusakiewicz, Philippe Langella, Harry Sokol, Guido Kroemer, David Enot, Antoine Roux, Alexander Eggermont, Eric Tartour, Ludger Johannes, Paul-Louis Woerther, Elisabeth Chachaty, Jean-Charles Soria, Encouse Golden, Silvia Formenti, Magdalena Plebanski, Mutsa Madondo, Philip Rosenstiel, Didier Raoult, Vincent Cattoir, Ivo Gomperts Boneca,
Mathias Chamaillard, and Laurence Zitvogel. Enterococcus hirae and Barnesiella intestinihominis Facilitate Cyclophosphamide-Induced Therapeutic Immunomodulatory Effects. Immunity, 45(4):931943, October 2016. doi: 10.1016/j.immuni.2016.09. 009.

[69] Kozue Takeshita, Shinta Mizuno, Yohei Mikami, Tomohisa Sujino, Keiichiro Saigusa, Katsuyoshi Matsuoka, Makoto Naganuma, Tadashi Sato, Toshihiko Takada, Hirokazu Tsuji, Akira Kushiro, Koji Nomoto, and Takanori Kanai. A Single Species of Clostridium Subcluster XIVa Decreased in Ulcerative Colitis Patients. Inflammatory Bowel Diseases, 22(12):2802-2810, December 2016. doi: 10.1097/ MIB.0000000000000972.

[70] Tasuku Ogita, Yoshinari Yamamoto, Ayane Mikami, Suguru Shigemori, Takashi Sato, and Takeshi Shimosato. Oral Administration of Flavonifractor plautii Strongly Suppresses Th2 Immune Responses in Mice. Frontiers in immunology, 11:379, 2020. doi: 10.3389/fimmu.2020.00379.

[71] Seong Gyu Jeon, Hisako Kayama, Yoshiyasu Ueda, Takuya Takahashi, Takashi Asahara, Hirokazu Tsuji, Noriko M Tsuji, Hiroshi Kiyono, Ji Su Ma, Takashi Kusu, Ryu Okumura, Hiromitsu Hara, Hiroki Yoshida, Masahiro Yamamoto, Koji Nomoto, and Kiyoshi Takeda. Probiotic Bifidobacterium breve induces IL-10-producing Tr1 cells in the colon. PLoS Pathogens, 8(5):e1002714, 2012. doi: 10.1371/journal.ppat.1002714.

[72] Giorgio Ciprandi, Maria Angela Tosca, Manlio Milanese, Giacomo Caligo, and Vittorio Ricca. Cytokines evaluation in nasal lavage of allergic children after Bacillus clausii administration: a pilot study. Pediatric allergy and immunology: official publication of the European Society of Pediatric Allergy and Immunology, 15(2):148-151, April 2004. doi: 10.1046/j.1399-3038.2003.00102.x.

[73] Makoto Kinoshita, Hisako Kayama, Takashi Kusu, Tomoyuki Yamaguchi, Jun Kunisawa, Hiroshi Kiyono, Shimon Sakaguchi, and Kiyoshi Takeda. Dietary folic acid promotes survival of Foxp3+ regulatory $\mathrm{T}$ cells in the colon. Journal of immunology (Baltimore, Md. : 1950), 189(6):2869-2878, September 2012. doi: 10.4049/jimmunol.1200420.

[74] Audrey Rivière, Marija Selak, David Lantin, Frédéric Leroy, and Luc De Vuyst. Bifidobacteria and Butyrate-Producing Colon Bacteria: Importance and Strategies for Their Stimulation in the Human Gut. Frontiers in Microbiology, 7(1030):979, 2016. doi: 10.3389/fmicb.2016.00979.

[75] Abeer Arain and Chance Matthiesen. Vitamin $D$ deficiency and graft-versus-host disease in 
medRxiv preprint doi: https://doi.org/10.1101/2020.04.08.20058198; this version posted June 9, 2020. The copyright holder for this preprint

(which was not certified by peer review) is the author/funder, who has granted medRxiv a license to display the preprint in perpetuity.

Revised manuscript It is made available under a CC-BY-NC-ND 4.0 International license .

hematopoietic stem cell transplant population. Hematology/oncology and stem cell therapy, 12(3): 133-139, September 2019. doi: 10.1016/j.hemonc. 2018.08.001.

[76] Estrella Carrillo-Cruz, José R García-Lozano, Francisco J Márquez-Malaver, Fermín M Sánchez-Guijo, Isabel Montero Cuadrado, Christelle Ferra I Coll, David Valcárcel, Oriana López-Godino, Marian Cuesta, Rocío Parody, Lucía López-Corral, Miguel Alcoceba, Teresa Caballero-Velázquez, Alfonso Rodríguez-Gil, José A Bejarano-García, Teresa Lopes Ramos, and José A Pérez-Simón. Vitamin D Modifies the Incidence of Graft-versusHost Disease after Allogeneic Stem Cell Transplantation Depending on the Vitamin D Receptor (VDR) Polymorphisms. Clinical cancer research : an official journal of the American Association for Cancer Research, 25(15):4616-4623, August 2019. doi: 10.1158/1078-0432.CCR-18-3875.

[77] W P Charteris, P M Kelly, L Morelli, and J K Collins. Antibiotic susceptibility of potentially probiotic Bifidobacterium isolates from the human gastrointestinal tract. Letters in applied microbiology, 26 (5):333-337, May 1998. doi: 10.1046/j.1472-765x. 1998.00342.

[78] C Moubareck, F Gavini, L Vaugien, M J Butel, and F Doucet-Populaire. Antimicrobial susceptibility of bifidobacteria. Journal of Antimicrobial Chemotherapy, 55(1):38-44, January 2005. doi: 10.1093/jac/ dkh495.

[79] K S Lim, C S Huh, and Y J Baek. Antimicrobial susceptibility of bifidobacteria. Journal of Dairy Science, 76(8):2168-2174, August 1993. doi: 10.3168/jds. S0022-0302(93)77553-0.

[80] E Kheadr, N Dabour, C Le Lay, C Lacroix, and I Fliss. Antibiotic susceptibility profile of bifidobac- teria as affected by oxgall, acid, and hydrogen peroxide stress. Antimicrobial agents and chemotherapy, 51(1):169-174, January 2007. doi: 10.1128/ AAC.00261-06.

[81] Teresa Graziano, Angela Amoruso, Stefania Nicola, Francesca Deidda, Serena Allesina, Marco Pane, Pietro Piffanelli, Francesco Strozzi, Luca Mogna, and Mario Del Piano. The Possible Innovative Use of Bifidobacterium longum W11 in Association With Rifaximin: A New Horizon for Combined Approach? Journal of clinical gastroenterology, 50 Suppl 2, Proceedings from the 8th Probiotics, Prebiotics \& New Foods for Microbiota and Human Health meeting held in Rome, Italy on September 13-15, 2015:S153-S156, November 2016. doi: 10.1097/MCG.0000000000000683.

[82] Muna Qayed, Amelia Langston, Kuang-Yueh Chiang, Keith August, Joseph A Hilinski, Conrad R Cole, Andre Rogatko, Roberd M Bostick, and John T Horan. Rifaximin for preventing acute graft-versushost disease: impact on plasma markers of inflammation and T-cell activation. Journal of pediatric hematology/oncology, 35(4):e149-52, May 2013. doi: 10.1097/MPH.0b013e31827e56af.

[83] D Weber, P J Oefner, K Dettmer, A Hiergeist, J Koestler, A Gessner, M Weber, F Stämmler, J Hahn, D Wolff, W Herr, and E Holler. Rifaximin preserves intestinal microbiota balance in patients undergoing allogeneic stem cell transplantation. Bone marrow transplantation, 51(8):1087-1092, August 2016. doi: $10.1038 / \mathrm{bmt} .2016 .66$.

[84] A Abbrescia, L L Palese, S Papa, A Gaballo, P Alifano, and Anna M Sardanelli. Antibiotic Sensitivity of Bacillus clausii Strains in Commercial Preparation. Clinical Immunology, Endocrine and Metabolic Drugs, 1(2):1-9, June 2014. doi: 10.2174/ 2212707002666150128195631. 